\title{
Isolation and multiplex genotyping of polymorphic microsatellite DNA markers in the snakehead murrel, Channa striata
}

\author{
Amirul Firdaus Jamaluddin Jamsari ${ }^{1}$, Tan Min-Pau ${ }^{1}$ and Mohd Nor Siti-Azizah ${ }^{1,2}$ \\ ${ }^{1}$ School of Biological Sciences, Universiti Sains Malaysia, Penang, Malaysia. \\ ${ }^{2}$ Centre for Marine and Coastal Studies, Universiti Sains Malaysia, Penang, Malaysia.
}

\begin{abstract}
Seven polymorphic microsatellite loci were isolated and characterized for the snakehead murrel, Channa striata (Channidae), a valuable tropical freshwater fish species. Among 25 specimens collected from Kedah state in Malaysia, the number of alleles per locus ranged from 2 to 7 . Observed and expected heterozygosities ranged from 0.120 to 0.880 and 0.117 to 0.698 , respectively. A single locus (CS1-C07) was significantly deviated from Hardy-Weinberg equilibrium after Bonferroni correction. These novel markers would be useful for population genetic studies of the $C$. striata.
\end{abstract}

Key words: Channa striata, population genetics, microsatellite, multiplex PCR.

Received: June 28, 2010; Accepted: November 22, 2010.

The snakehead murrel, Channa striata (Perciformes, Channoidei, Channidae) or haruan as it is locally known in Malaysia, is an indigenous tropical freshwater fish that is widely distributed across Southeast Asia, South Asia, and Southern China (Talwar and Jhingran, 1992). This sub-cylindrical fish can grow up to $100 \mathrm{~cm}$ in length and is found in rice fields, rivers, swamps, ponds, canals and lakes especially in areas infested by thick aquatic vegetation (Ali, 1999; Froese and Pauly, 2010). This carnivorous air-breather is renowned as a food fish and proven to have medical and pharmaceutical properties especially for wound healing (Mat Jais et al., 1994; Michelle et al., 2004). The demand for the species is increasing, and it is usually marketed alive, fetching a price of around USD 6/kg. Because of its commercial value, it is highly exploited in the wild. Aquaculture activity of this species is still low in Malaysia probably due to its presumed abundance in the natural habitats. However, anthropogenic effects such as overfishing, development, river flow regulation and pollution are expected to introduce pressure to the population and lead to population fragmentation and decline. Therefore, monitoring the population genetic status is essential to provide crucial information in stock evaluation of the species for both wild and cultivated population management and conservation. In the present study, we developed seven microsatellite markers for C. striata using the protocol by Edwards et al. (1996) modified according to Jones et al. (2001).

Send correspondence to Mohd Nor Siti-Azizah. School of Biological Sciences, Universiti Sains Malaysia, 11800 Minden, Penang, Malaysia. E-mail: sazizah@usm.my.
Genomic DNA extraction from fin-clip tissue of a single snakehead murrel was performed using standard phenol-chloroform method modified from Taggart et al. (1992). The extract was then digested with RsaI and fragments were ligated to a $M l u \mathrm{I}$ adaptor. Amplification reactions were conducted in a $50 \mu \mathrm{L}$ reaction mixture containing $5 \mathrm{ng}$ of ligated DNA, $250 \mathrm{ng}$ of one of the primers corresponding to the MluI adaptor, $1 \mathrm{X}$ PCR buffer, $2.5 \mathrm{mM}$ $\mathrm{MgCl}_{2}, 0.2 \mathrm{mM}$ dNTPs, $0.02 \mu \mathrm{M}$ each primer, and $2 \mathrm{U}$ Ampli Taq Gold (Applied Biosystems). Polymerase chain reactions $(\mathrm{PCR})$ were performed with the following profile: initial denaturation at $95^{\circ} \mathrm{C}$ for $10 \mathrm{~min}$ followed by $30 \mathrm{cy}$ cles consisting of $94^{\circ} \mathrm{C}$ for $15 \mathrm{~s}, 60^{\circ} \mathrm{C}$ for $1 \mathrm{~min}, 72^{\circ} \mathrm{C}$ for $3 \mathrm{~min}$, and a final extension at $72{ }^{\circ} \mathrm{C}$ for $15 \mathrm{~min}$. Microsatellite enrichment was performed by hybridization to a Hybond-N+ membrane containing the microsatellite probes $(\mathrm{GACA})_{9},(\mathrm{GATA})_{9},(\mathrm{AAAT})_{9},(\mathrm{GATA})_{9},(\mathrm{CAA})_{14}$, $(\mathrm{CA})_{20},(\mathrm{GT})_{15},(\mathrm{AAT})_{14},(\mathrm{CT})_{15}$, and $(\mathrm{AAG})_{14}$. The eluted microsatellite-enriched DNA was amplified using the same PCR conditions as above and purified using a MicroSpin S-300 column (Pharmacia). The PCR product was then ligated into pGEM T-Easy Vector (Promega) and transformed into Escherichia coli JM109 competent cells (Promega). 96 recombinant colonies were picked from LB agar plates containing ampicillin, IPTG, and X-gal. Subsequently, their plasmids were amplified using TempliPhi (GE Healthcare) and inserts were sequenced using the automated sequencer (ABI PRISM 3730XL) and an ABI PRISM BigDye terminator cycle sequencing kit version 3.1 (Applied Biosystems). 
From the total recombinant plasmids sequenced, 27 sequences contained good signal data with at least eight repeat microsatellite motifs. Vector sequences were detected using Chromas version 2.33 and removed. PRIMER 3 (Rozen and Skaletzky, 2000) was used to design the primers. Primers to the flanking regions of each microsatellite were designed for 11 microsatellite loci, with forward primers being labeled with fluorescent dye. However, based on preliminary assessment on several individuals, only seven loci produced good amplification with allele size polymorphism and were considered robust for subsequent analyses (Table 1). These sequences were deposited in GenBank (accession numbers GU321675, GU321677 to GU321682).

25 individuals of $C$. striata collected from the state of Kedah (Malaysia), with geographical location $6^{\circ} 14^{\prime} \mathrm{N}$ $100^{\circ} 36^{\prime} \mathrm{E}$, were then assayed for the seven microsatellites. PCR amplifications were performed in a $6.25 \mu \mathrm{L}$ reaction volume containing $10 \mathrm{ng}$ of genomic DNA, 2X QIAGEN Multiplex PCR Master Mix and $0.2 \mu \mathrm{M}$ of each forward and reverse primer. The PCR protocol consisted of an initial $95{ }^{\circ} \mathrm{C}$ for $15 \mathrm{~min}$ followed by 29 cycles of $94{ }^{\circ} \mathrm{C}$ for $30 \mathrm{~s}, 57^{\circ} \mathrm{C}$ for $1.5 \mathrm{~min}, 72{ }^{\circ} \mathrm{C}$ for $1 \mathrm{~min}$, and finally $30 \mathrm{~min}$ of final extension at $60^{\circ} \mathrm{C}$. Allelic data was analyzed using Peak Scanner v1.0 software (Applied Biosystems) with GS500 (Applied Biosystems) as the internal size standard. Arlequin version 3.1 (Excoffier et al., 2005) was used to calculate the allele frequency, observed $\left(H_{O}\right)$, and expected $\left(H_{E}\right)$ heterozygosities, to test deviations from Hardy-Weinberg equilibrium (HWE) and pairwise comparisons of all loci for linkage disequilibrium (LD). Bonferroni corrections were applied with a global significance level of 0.05 to account for multiple testing in HWE and LD tests. The presence of null alleles, large allele dropout, and scoring errors due to stutter peaks were assessed using MicroChecker v2.2.3 (Van Oosterhout et al., 2004).

Table 1 shows the characteristics of the seven novel C. striata microsatellite loci. No evidence for the presence of null alleles, large allele dropout, and scoring error due to stuttering was observed. The number of alleles per locus ranged from two to seven. The observed and expected heterozygosities ranged from 0.120 to 0.880 (with an average of 0.520 ) and from 0.117 to 0.698 (with an average of 0.482), respectively. Deviation from Hardy-Weinberg equilibrium was detected at a single locus (CS1-C07), which showed significant excess of heterozygosity. The significant heterozygosity excess in CS1-C07 suggests the possibility of ancient and recent demographic events, i.e., bottleneck effect (Cornuet and Luikart, 1996; Riccioni et al., 2010). Overall, markers developed in this study would be useful in assessing the level of genetic diversity and population structure for breeding strategy, fishery management, and conservation of this species.

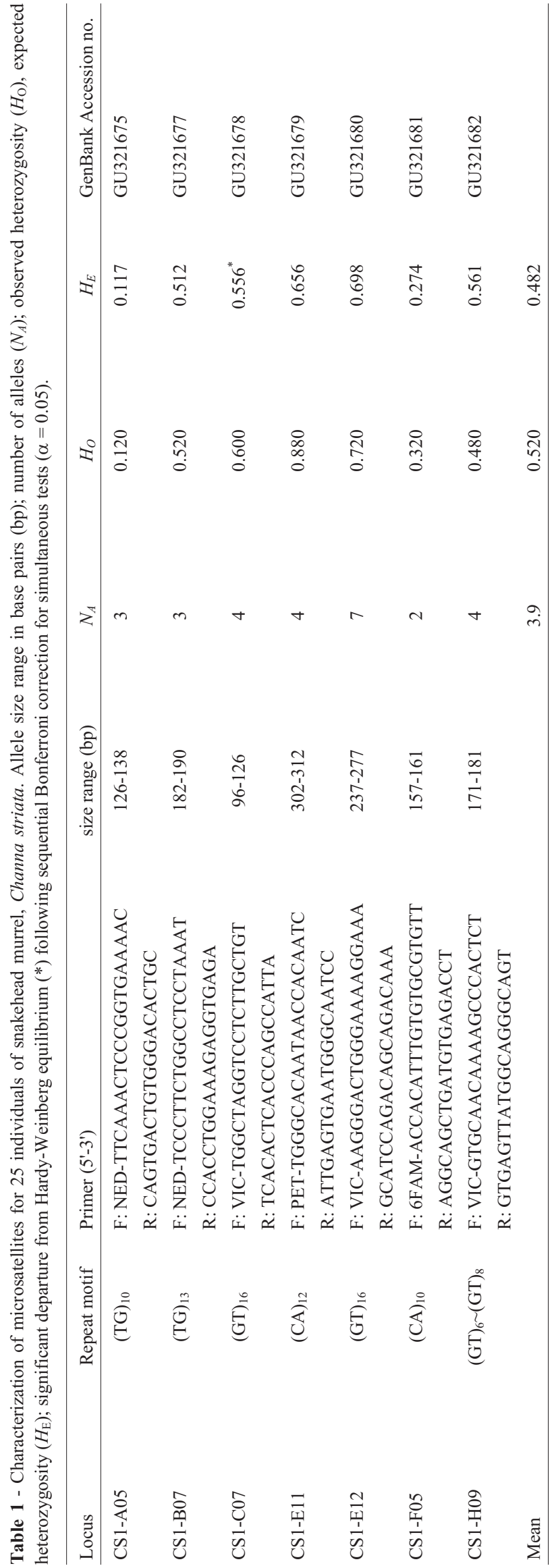




\section{Acknowledgments}

This study was funded by Universiti Sains Malaysia (Research University Grant) (1001/PBIOLOGI/8750123) under the Malaysian Ministry of Science, Technology and Innovation (MOSTI). We would like to thank Dr. Thuy T.T. Nguyen from Network of Aquaculture Centres in Asia-Pacific (NACA), Bangkok, Thailand for her technical assistance.

\section{References}

Ali AB (1999) Aspects of the reproductive biology of female snakehead (Channa striata Bloch) obtained from irrigated rice agroecosystem, Malaysia. Hydrobiologia 411:71-77.

Cornuet JM and Luikart G (1996) Description and power analysis of two tests for detecting recent population bottlenecks from allele frequency data. Genetics 144:2001-2014.

Edwards KJ, Barker JHA, Daly A, Jones C and Karp A (1996) Microsatellite libraries enriched for several microsatellite sequences in plants. BioTechniques 20:758-760.

Excoffier L, Laval LG and Schneider S (2005) Arlequin v. 3.0: An integrated software package for population genetics data analysis. Evol Bioinform Online 1:47-50.

Jones ES, Dupal MP, Kolliker R, Drayton MC and Forster JW (2001) Development and characterization of simple sequence repeat (SSR) markers for perennial ryegrass (Lolium perenne L.). Theor Appl Genet 102:405-415.

Mat Jais AM, McCulloh R and Croft K (1994) Fatty acid and amino acid composition in haruan as a potential role in wound healing. Gen Pharmacol 25:947-950.
Michelle NYT, Shanti G and Loqman MY (2004) Effect of orally administered Channa striatus extract against experimentally-induced osteoarthritis in rabbits. Int J Appl Res Vet Med 2:171-175.

Riccioni G, Landi M, Ferrara G, Milano I, Cariani A, Zane L, Sella M, Barbujani G and Tinti F (2010) Spatio-temporal population structuring and genetic diversity retention in depleted Atlantic bluefin tuna of the Mediterranean Sea. Proc Natl Acad Sci USA 107:2102-2107.

Rozen S and Skaletzky HJ (2000) Primer 3 on the WWW for general users and for biologist programmers. In: Krawetz $\mathrm{S}$ and Misener S (eds) Bioinformatics Methods and Protocols: Methods in Molecular Biology. Humana Press, New Jersey, pp 365-386.

Taggart JB, Hynes RA, Prodohl PA and Ferguson A (1992) A simplified protocol for routine total DNA isolation from salmonid fishes. J Fish Biol 40:963-965.

Talwar PK and Jhingran AG (1992) Inland Fishes of India and Adjacent Countries. v. 2. A.A. Balkema, Rotterdam, 1158 pp.

Van Oosterhout C, Hutchinson WF, Wills DPM and Shipley PF (2004) MICRO-CHECKER: For identifying and correcting genotyping errors in microsatellite data. Mol Ecol Notes 4:535-538.

\section{Internet Resources}

Froese R and Pauly D (eds) (2010) FishBase. www.fishbase.org (November, 2010).

Associate Editor: Louis Bernard Klaczko

License information: This is an open-access article distributed under the terms of the Creative Commons Attribution License, which permits unrestricted use, distribution, and reproduction in any medium, provided the original work is properly cited. 